\title{
Testament własnoręczny \\ w świetle ustawodawstwa Królestwa Polskiego i praktyki na przykładzie akt kancelarii notarialnych w Zgierzu w latach 1826-1875
}

1. Uwagi wstępne. Testament własnoręczny był, obok testamentu publicznego i testamentu tajemnego, formą rozporządzenia ostatniej woli uregulowaną w Kodeksie Napoleona. Sporządzenie testamentu własnoręcznego, w przeciwieństwie do pozostałych form, nie wymagało zachowania jakichkolwiek ram urzędowych ani udziału osób trzecich. Testator miał tu najpełniejszą możliwość zachowania w tajemnicy dokonanych dyspozycji majątkowych, a fakt ograniczonych wymogów formalnych minimalizował ryzyko nieważności takiego aktu. Mimo oczywistych zalet testament własnoręczny krył też pewne niebezpieczeństwa ${ }^{1}$.

Pismo obejmujące ostatnią wolę nie musiało być nazwane wprost testamentem (własnoręcznym). Za taki mógł być uznany np. list pisany w całości przez spadkodawcę, datowany i podpisany, jeżeli z jego treści wynikało, iż pragnie nim dokonać dyspozycji na wypadek śmierci ${ }^{2}$. Jak też rewers pisany własnoręcznie datowany i podpisany, w którym mąż wyjawił wolę, aby suma objęta rewersem została wypłacona żonie ${ }^{3}$.

Mimo oczywistych zalet praktyka zgierskiego notariatu ${ }^{4}$ daje podstawę do sformułowania wniosku, iż rozporządzenia majątkiem na wypadek śmierci $\mathrm{w}$ formie testamentu własnoręcznego zdarzały się rzadko. W analizowanych

\footnotetext{
${ }^{1}$ Przede wszystkim akt taki narażony był na ryzyko sfałszowania, np. przez pominiętych w nim krewnych.

2 J.J. Litauer, Prawo cywilne obowiqzujace na obszarze b. Kongresowego Królestwa z dodaniem tekstu francuskiego, ustaw uzupetniajacych $i$ zwiqzkowych oraz orzecznictwa kasacyjnego, Warszawa 1929 , s. 291.

${ }^{3}$ M. Kurman, Prawo spadkowe. Prawo hipoteczne. Ustawodawstwo z okresu wojny. Pytania do aktów. Schematy aktów, Warszawa 1918, s. 49.

${ }^{4}$ Bazę źródłową dla niniejszego artykułu stanowią akta notariuszy zgierskich za lata 1826-1875, znajdujące się w Archiwum Państwowym w Łodzi.
} 
zbiorach odnajdujemy jedynie 10 protokołów posiedzeń sądowych w przedmiocie otwarcia testamentu własnoręcznego ${ }^{5}$, z czego w 4 przypadkach $\mathrm{w}$ aktach nie zachowała się treść rozporządzenia ${ }^{6}$.

Mimo tak skromnego zasobu źródeł praktyki chcemy pokusić się o przedstawienie dających się na tej podstawie sformułować uwag? ${ }^{7}$.

\section{Wymogi formalne.}

2.1. Pismo własnoręczne. Podstawowym warunkiem ważności aktu ostatniej woli był obowiązek sporządzenia go własnoręcznie przez testatora ${ }^{8}$. Dlatego też Departament IX Senatu w orzeczeniu z 1859 r. stał na stanowisku, iż pismo obejmujące legaty i dołączone do testamentu, chociażby było podpisane przez testatora i powołane w testamencie, nie ma mocy obowiązującej, o ile nie zostało napisane jego ręką .

Dodajmy, iż dla doktryny napisanie chociażby jednego słowa obcą ręką na dokumencie obejmującym rozporządzenie ostatniej woli pociąga za sobą nieważność nie tylko dopisku, ale i całego aktu ${ }^{10}$. Co prawda M. Planiol podnosił, iż nie każdy wyraz dopisany przez inną osobę powoduje nieważność rozporządzenia ostatniej woli, a tylko wpleciony w tekst oświadczenia. Natomiast wszelkie cudze dopiski znajdujące się nad lub pod treścią testamentu ważności całego aktu nie podważają ${ }^{11}$. Z kolei zdaniem J.J. Delsola dopisanie czegokolwiek obcą ręką, bez udziału testatora, nie podważało ważności testamentu ${ }^{12}$. Pogląd ten należy uznać za oczywiście słuszny. Wyrazy znajdujące się na dokumencie ostatniej woli, a niepochodzące od zapisodawcy niezależnie od miejsca umieszczenia, nigdy nie powinny wpływać na ważność całości dyspozycji testamentowych. W przeciwnym razie każdy w czyim ręku znalazłby się testament mógłby bez trudu pozbawić go ważności.

Pewne wątpliwości zgłaszano natomiast co do sytuacji, gdy zapisodawca sporządził akt przy pomocy osoby trzeciej, która prowadziła mu rękę. Choć

${ }^{5}$ Roman Jaroński, sygn. 52, 53, 284, Józef Stokowski, sygn.6565, 2106, 6379, 2850, 3156, 1386, Jan Cichocki, sygn. 870.

${ }^{6}$ Roman Jaroński, sygn. 52, 53, 284, Józef Stokowski, sygn. 6565.

${ }^{7}$ Dla porównania wskażmy, iż w tym samym okresie w aktach notariuszy zgierskich odnajdujemy 319 testamentów publicznych.

${ }^{8}$ Art. 970 KN. Testament własnoręczny nie będzie ważnym, jeżeli nie jest pisany w całości, datowany i podpisany ręką testatora; nie ulega on żadnej innej formie.

${ }^{9}$ M. Kurman, Prawo spadkowe. Prawo hipoteczne..., s. 49.

${ }^{10}$ Np.: H. Cederbaum, Jak napisać testament wtasnoręczny, Warszawa 1900, s. 118; M. Kurman, Prawo spadkowe. Prawo hipoteczne. Ustawodawstwo z okresu wojny. Pytania do aktów. Schematy aktów, Warszawa 1918; A. Okolski, Zasady prawa cywilnego obowiqzujace w Królestwie Polskim; Warszawa 1885.

${ }^{11}$ M. Planiol, Podręcznik prawa cywilnego (o darowiznach i testamentach), z francuskiego przełożył i przypisami opatrzył A. Słomiński, Warszawa 1922, s. 83.

12 J.J. Delsol, Zasady Kodeksu Napoleona w zwiazku z nauka i jurysprudencja, t. II, Warszawa 1874, s. 251-252. 
większość autorów odmawiała ważności takiemu dokumentowi ${ }^{13}$, to M. Planiol i H. Konica wskazują, iż testament taki należy uznać za spełniający wymogi formalne, jeżeli nie zachodzą wątpliwości co do samodzielności i swobody decyzji testatora ${ }^{14}$.

Praktyka zgierska nie pozwala na rozstrzygnięcie poważnych wątpliwości. Choć protokoły posiedzeń sądowych nie zawierają żadnych wzmianek o potwierdzeniu w jakikolwiek sposób własnoręczności pisma testatora, to dokumenty znajdujące się w aktach notarialnych zasadniczo nie dają podstaw do twierdzenia, iż nie przestrzegano wymogu własnoręczności $i^{15}$.

$\mathrm{Z}$ protokołu posiedzenia Trybunału Cywilnego Guberni Warszawskiej z dnia 6/18 maja 1852 r. wynika, iż testament Łukasza Michalaka nie został spisany przez testatora: „pismo to obcą ręką sporządzone mieści się na jednej stronie". Jednakże z dokumentu nie wiadomo, na jakiej podstawie sąd wysnuł taki wniosek. Najprawdopodobniej wynikało to z faktu, iż pod treścią rozporządzenia zapisodawca postawił znaki trzech krzyży, a obok wypisano jego imię i nazwisko. Ponadto na dokumencie znajdują się także w postaci znaków krzyży podpisy dwóch świadków czynności, obok których wypisano także ich imiona i nazwiska. Zauważmy, iż protokół nie zawiera wzmianki o nieważności dokumentu jako testamentu własnoręcznego, choć brak przepisanych prawem wymogów formalnych był oczywisty ${ }^{16}$.

Ustawodawca nie określił, na czym testament powinien zostać sporządzony. Tak też zapisodawca miał możliwość uzewnętrznienia swojej ostatniej woli nie tylko na papierze, ale - jak wskazuje doktryna - na przykład na murze więziennym czy też szpitalnej ścianie ${ }^{17}$. Podobnie Kodeks Napoleona pozostawiał dowolność co do języka, w jakim rozporządzenie mogło być dokonane.

Testamenty własnoręczne prawie zawsze były pisane $\mathrm{w}$ języku polskim ${ }^{18}$. Jedynie z protokołu posiedzenia Trybunału Pierwszej Instancji Guberni Warszawskiej z dnia 28 kwietnia/10 maja 1852 r. wynika, iż oświadczenie woli Joanny Adelajdy Winklerowej zostało spisane w języku niemieckim. Niestety treść tego testamentu nie zachowała się w aktach notarialnych ${ }^{19}$.

${ }^{13}$ H. Cederbaum, Jak napisać testament wtasnoręczny, Warszawa 1900, s. 118.

${ }^{14}$ Prawo cywilne obowiazujace $w$ b. Królestwie Polskim, Repertorium egzaminacyjne opracowane na podstawie wykładów uniwersyteckich prof. K. Lutostańskiego i prof. H Konica, Uzupetnione i poprawione z uwzględnieniem zmian wprowadzonych do prawa cywilnego, przez ustawy i rozporzqdzenia oraz nowy kodeks zobowiqzań. Zawiera: Rys historyczny, prawo osobowe, prawo familijne, prawo matżeńskie osobowe, stosunki majątkowe pomiędzy matżonkami, prawo rzeczowe i hipoteczne, spadki, testamenty, wyd. IV, Warszawa 1935 r.; M. Planiol, Podręcznik prawa cywilnego (o darowiznach i testamentach), z francuskiego przełożył i przypisami opatrzył A. Słomiński, Warszawa 1922, s. 83.

${ }^{15} \mathrm{~Np} .:$ Roman Jaroński, sygn. 284.

${ }^{16} \mathrm{JW}$., sygn. 53.

${ }^{17}$ M. Kurman, Prawo spadkowe. Prawo hipoteczne..., s. 49.

${ }^{18} \mathrm{~Np}$.: Józef Stokowski, sygn. 6379.

${ }^{19}$ Roman Jaroński, sygn. 5006. 
2.2. Data. Kolejnym warunkiem ważności testamentu własnoręcznego, wynikającym z art. $970 \mathrm{KN}$, był obowiązek datowania pisma. Regulacja ta była podyktowana dwoma powodami. Z jednej strony, data pozwalała ocenić zdolność testatora do dokonywania rozporządzeń majątkowych na wypadek śmieci, a z drugiej wskazywała, w przypadku istnienia kilku rozporządzeń, które $\mathrm{z}$ nich jest ostatnie, a zatem podlegające wykonaniu ${ }^{20}$.

Data powinna być określona przez wskazanie dnia, miesiąca i roku ${ }^{21}$. Jednakże nie musiało to nastąpić w wyrażeniach ściśle kalendarzowych, o ile nie powstawała wątpliwość co do momentu sporządzenia dokumentu, np. Boże Narodzenie 1866 r.

Jeżeli testament opatrzony został datą fałszywą lub mylną, był nieważny, o ile treść aktu nie pozwalała na ustalenie prawdziwej daty jego sporządzenia. Niedopuszczalnym natomiast było oznaczenie daty za pomocą środków dowodowych pochodzących spoza testamentu ${ }^{22}$.

Kodeks Napoleona nie oznaczał miejsca, w którym należało umieścić datę. Dlatego też mogła ona zostać umieszczona dowolnie, na początku lub końcu aktu. Mogło się zdarzyć, iż rozporządzenie ostatniej woli zostało opatrzono dwiema datami, wcześniejszą na początku aktu i późniejszą na jego końcu. Taka okoliczność nie podważała ważności dokumentu, gdyż oznaczała ona jedynie, iż testament rozpoczęto pisać pod datą wcześniejszą, a zakończono pod późniejszą. Jednakże odwrotna sytuacja była już niedopuszczalna ${ }^{23}$.

Zgodnie z postanowieniem Rady Administracyjnej z 1835 r. w aktach urzędowych należało stosować datę podwójną, według kalendarza juliańskiego i gregoriańskiego ${ }^{24}$. Mimo iż regulacja ta nie odnosiła się do dokumentów prywatnych, zdarzało się, iż testamenty własnoręczne zawierały podwójną datę. Dlatego też w doktrynie podnoszono, iż w takim przypadku należy oznaczyć datę według kalendarza juliańskiego ${ }^{25}$.

W praktyce testatorzy przestrzegali obowiązku datowania swych rozporządzeń ostatniej woli. Wszystkie zachowane akty (6) są datowane. Zaś pozostałe 4 protokoły posiedzeń sądowych również nie zawierają jakiejkolwiek wzmianki o niezachowaniu przez któregokolwiek z testatorów tego wymogu ${ }^{26}$. W kwestii miejsca czy sposobu oznaczania daty nie widać jednolitej zasady. W 3 przypadkach data została umieszczona na początku ${ }^{27}$, a w 3 na końcu doku-

${ }^{20}$ A. Okolski, Zasady prawa cywilnego..., s. 399.

${ }^{21}$ M. Kurman, Prawo spadkowe. Prawo hipoteczne..., s. 50.

${ }^{22}$ J.J. Delsol, Zasady Kodeksu Napoleona, t. II, s. 252.

${ }^{23} \mathrm{~F}$. Podlewski, O spadkach i testamentach. Wyktad popularny prawa obowiqzujacego z uwzględnieniem prawa rosyjskiego, austriackiego i niemieckiego, Warszawa 1900, s. 127.

${ }^{24}$ S. Zawadzki, Prawo cywilne obowiqzujace w Królestwie Polskim, t. I, Warszawa 1860, t. II, Warszawa 1861, s. 875. Różnica między obiema datami wynosiła 12 dni.

${ }^{25} \mathrm{~F}$. Podlewski, O spadkach i testamentach..., s. 127.

${ }^{26}$ Roman Jaroński, sygn. 52, 53, 284, Józef Stokowski, sygn. 6565.

${ }^{27}$ Józef Stokowski, sygn. 63, 1386, Jan Cichocki 870. 
mentu $^{28}$. Zapisodawcy wskazywali czas sporządzenia dokumentu, oznaczając cyframi dzień i rok, a literami miesiąc, np. 24 lutego 1833 roku ${ }^{29}$, bądź literami np. dwudziestego piatego lutego tysiac osmset trzydziestego piatego roku ${ }^{30}$. Wskażmy jeszcze, iż spośród 3 aktów sporządzonych po wejściu w życie postanowienia Rady Administracyjnej z 1835 r., 2 są opatrzone podwójną datą ${ }^{31}$.

2.3. Podpis. Kolejnym wymogiem stawianym przez art. $970 \mathrm{KN}$ testamentowi własnoręcznemu był obowiązek podpisania aktu przez zapisodawcę. Przepisy nie wskazywały miejsca umieszczenia podpisu, gdyż oczywistym jest, iż powinien znajdować się on na końcu. W przeciwnym razie nie można byłoby stwierdzić, czy testator zakończył swoją dyspozycję. Jeżeli pod podpisem znajdowałyby się jeszcze jakieś rozporządzenia, powinny one pod rygorem nieważności zostać ponownie podpisane ${ }^{32}$.

Kodeks Napoleona nie wymagał, aby podpis składał się z pełnego imienia i nazwiska, jednakże musiał on być na tyle czytelny, aby nie zachodziła wątpliwość co do osoby testatora. Dlatego też za podpis nie mogły być uważane znaki krzyży, jako niedające możliwości dostatecznej identyfikacjii3 ${ }^{33}$.

Stwierdziliśmy, iż tylko w jednym przypadku testator nie złożył własnoręcznego podpisu. We wspomnianym już wyżej protokole posiedzenia Trybunału Cywilnego Guberni Warszawskiej z dnia 6/18 maja 1852 r. wskazano, iż testament Łukasza Michalaka został spisany obcą ręką, a testator postawił jedynie znaki trzech krzyży, przy których wypisano jego imię i nazwisko ${ }^{34}$. Co oczywiste - taki dokument nie mógł zostać uznany za testament własnoręczny.

Testatorzy podpisywali się prawie zawsze pełnym imieniem (imionami) i nazwiskiem (nazwiskami), np. Ludwik Koroniewski ${ }^{35}$, Michał Józef Smoleński ${ }^{36}$, Tekla z Oskowskich ostatniego ślubu Borowska ${ }^{37}$.

Mimo iż prawo nakazywało podpisanie rozporządzenia jedynie przez testatora, to ewentualne podpisy innych osób pod tekstem testamentu nie skutkowały jego nieważnością ${ }^{38}$. I taki przypadek ważnie sporządzonego testamentu własnoręcznego zeznanego w obecności świadków odnotowuje jeden raz nasza praktyka. Na rozporządzeniu ostatniej woli Augusta Lambrechta z dnia 24 lutego 1833 r. znajdują się podpisy 5 osób z adnotacją: obecny, np. „obecny

\footnotetext{
${ }^{28}$ Józef Stokowski, sygn. 2850, 3156, 6379.

${ }^{29} \mathrm{JW}$., sygn. 3156.

${ }^{30} \mathrm{JW}$., sygn. 2850.

${ }^{31}$ JW., sygn. 6379, Jan Cichocki 870.

${ }^{32}$ A. Okolski, Zasady prawa cywilnego..., s. 399.

${ }^{33}$ J.J. Delsol, Zasady Kodeksu Napoleona..., t. II, s. 253.

${ }^{34}$ Roman Jaroński, sygn. 53.

${ }^{35}$ Józef Stokowski, sygn. 2106.

${ }^{36}$ Jan Cichocki, sygn. 870.

${ }^{37}$ Józef Stokowski, sygn. 1386.

${ }^{38}$ F. Podlewski, O spadkach i testamentach ..., s. 129.
} 
Czapliński Michał". Zaś szósty świadek postawił jedynie znaki trzech krzyży, a obok wypisano jego imię i nazwisko. Niestety w tekście brak jest jakichkolwiek informacji o powodach spisania ostatniej woli w obecności świadków, czy też kim były dla testatora te osoby ${ }^{39}$.

W dokumencie z dnia 20 stycznia 1829 r., sporządzonym i podpisanym przez Ludwika Rakowieckiego, znajdujemy podpisy dwóch osób: Wincentego Garczyńskiego i Antoniego Wilczyckiego. Jednakże jak wynika z protokołu sądowego otwarcia testamentu obywatele ci nie byli obecni przy spisywaniu oświadczenia woli przez Ludwika Rakowieckiego, a tylko w późniejszym czasie na prośbę testatora złożyli podpisy, jak się wydaje na dowód, iż pismo to jest testamentem własnoręcznym spadkodawcy:

iż żyiąc [oświadczenie Wincentego Garczyńskiego] z Ludwikiem Rakowieckim w stosunkach ścisłej przyjaźni, może na cztery tygodnie przed zgonem jego pewnego razu sam przybywszy z wizytą do niego, oświadczył, iż sporządził, czyli własnoręcznie spisał sobie ostatnią swą wolę, ta aby była w ręku jego [Wincentego Garczyńskiego] do zgonu życia, okazał otwartą do odczytania oddał i aby była przez nas podpisana domagał się. To działo się $\mathrm{w}$ osobnym pokoiu przy obecności tylko stawaiących [Wincentego Garczyńskiego i Antoniego Wilczyckiego] i testatora i to zupełnie przy zdrowych zmysłach jego ${ }^{40}$.

\subsection{Przedstawienie testamentu Prezesowi Trybunału Cywilnego I In-} stancji. Testament własnoręczny nie mógł zostać wykonany zaraz po śmierci testatora, o ile nie dokonano pewnych czynności mających na celu nadanie mu cechy urzędowej. Formalności te miały na celu przede wszystkim zabezpieczenie rozporządzenia przed jego zniszczeniem lub sfałszowaniem w przyszłości ${ }^{41}$. Zgodnie $\mathrm{z}$ art. $1007 \mathrm{KN}$,

każdy testament własnoręczny, przed wykonaniem go, przedstawiony zostanie Prezesowi Trybunału pierwszej instancyi okręgu, w którym spadek się otworzył. Testament będzie otwarty, jeżeli był zapieczętowany. Prezes sporządzi protokół przedstawienia, otwarcia i stanu testamentu, sam zaś testament nakaże złożyć do zachowania wyznaczonemu przez siebie notariuszowi.

Obowiązek przedstawienia testamentu ${ }^{42}$ spoczywał na każdej osobie, w której posiadaniu się znalazł. Dokument powinien zostać dostarczony do Trybunału Cywilnego I Instancji okręgu, w którym zmarł spadkodawca. Mogło się jednakże zdarzyć, iż przedłożenie testamentu sądowi było niemożliwe,

\footnotetext{
${ }^{39}$ Józef Stokowski, sygn. 3156.

${ }^{40}$ Jw., sygn. 2106.

${ }^{41}$ M. Planiol, Podręcznik prawa cywilnego..., s. 88.

${ }^{42}$ Wraz z dołączonym aktem zgonu.
} 
gdyż np. został on spisany przez więźnia na ścianie celi. W takim przypadku Prezes Trybunału Cywilnego I Instancji sam musiał pofatygować się na miejsce, w którym oświadczenie znajdowało się, aby dokonać przepisanych prawem czynności ${ }^{43}$.

Zaznaczmy, iż zabronione było otwieranie zapieczętowanego testamentu czy też naruszanie go w jakikolwiek inny sposób ${ }^{44}$.

Prezes Trybunału Cywilnego I Instancji po otrzymaniu dokumentu wyznaczał dzień i godzinę otwarcia aktu oraz wzywał na posiedzenie znanych sobie spadkobierców, z tym że brak ich stawiennictwa nie wstrzymywał dokonania czynności ${ }^{45}$.

Z przeprowadzonej czynności Prezes sporządzał protokół, w którym wskazywał przez kogo testament został złożony, czy był zapieczętowany, czy otwarty. Ponadto w protokole powinien znaleźć się opis stanu rozporządzenia ostatniej woli, z wyszczególnieniem słów, od których się zaczynał i na których się kończył, liczby wierszy, a także wszelkich dostrzeżonych przekreśleń i poprawek ${ }^{46}$. Tak sporządzony protokół Prezes Trybunału Cywilnego Pierwszej Instancji wraz z testamentem przesyłał wybranemu przez siebie notariuszowi.

Badane źródła wskazują, iż w 8 przypadkach otwarcie testamentu i spisanie protokołu zostało dokonane przez Prezesa Trybunału Cywilnego I Instancji Województwa Mazowieckiego ${ }^{47}$. Zaś z 2 dokumentów wynika, iż czynność ta na podstawie upoważnienia Prezesa Trybunału Cywilnego I Instancji Województwa Mazowieckiego została dokonana przez Sędziego Pokoju Powiatu Zgierskiego ${ }^{48}$.

W piśmie Prezesa Trybunału Cywilnego I Instancji skierowanym do Sędziego Pokoju Powiatu Zgierskiego z dnia 10 marca 1829 r. czytamy:

przychylnie za prośbą Wdowy po niegdy Ludwiku Rakowieckim pozostałej upoważniam Sędziego, aby testament prywatny przez męża podającej sporządzony, a w zachowaniu Wincentego Garczyńskiego znajdujący się do Sądu ściąnnowszy takowy z zachowaniem formalności art. 1007 K.C. przepisanych, otworzył i zapublikował i do zachowania Rejentowi Stokowskiemu wraz z wypisem protokołu publikacji oddał, oraz protokół publikacji oryginalny do Trybunału nadesłał w dniach $20^{49}$.

Mimo iż art. 1007 KN nakładał obowiązek otwarcia i ogłoszenia testamentu prywatnego przez Prezesa Trybunału Cywilnego I Instancji, jak wynika

\footnotetext{
${ }^{43}$ J.J. Delsol, Zasady Kodeksu Napoleona..., t. II, s. 251.

${ }^{44} \mathrm{~F}$. Podlewski, O spadkach i testamentach, s. 144.

${ }^{45}$ Ibidem, s. 145.

${ }^{46} \mathrm{H}$. Cederbaum, Jak napisać testament własnoręczny, s. 126.

${ }^{47} \mathrm{~Np}$.: Józef Stokowski, sygn. 5378.

${ }^{48}$ JW., sygn. 2106, 3156.

${ }^{49} \mathrm{Jw}$., sygn. 2106.
} 
z przywołanego aktu, uprawnienie do scedowania tych kompetencji na sędziego pokoju wynikało z przepisów dotyczących organizacji sądownictwa. Możliwość ta miała istotne znaczenie praktyczne nie tylko dla Prezesa Trybunału Cywilnego I Instancji, ale także dla zainteresowanych stron, które często mogły mieć problem $\mathrm{z}$ osobistym stawiennictwem w Trybunale.

W większości przypadków protokoły otwarcia i ogłoszenia testamentu własnoręcznego były sporządzane prawidłowo, zgodnie z wymogami wynikającymi z art. $1007 \mathrm{KN}$.

W pierwszej kolejności protokoły zawierały imiona i nazwiska osób składających testament przed sądem celem jego otwarcia i ogłoszenia. W tym zakresie tylko 1 dokument nie zawiera takich danych ${ }^{50}$.

Rozporządzenia ostatniej woli przedkładali do otwarcia i ogłoszenia najczęściej członkowie najbliższej rodziny, np. pozostały przy życiu małżonek ${ }^{51}$ lub rodzic $^{52}$. Zdarzało się jednakże, iż czynności tej dokonywały osoby urzędowe, jak adwokat ${ }^{53}$, notariusz ${ }^{54}$, czy podsędek ${ }^{55}$. Nie wiadomo, w jaki sposób osoby te weszły w posiadanie testamentów własnoręcznych. Najpewniej zostały one zdeponowane przez zapisodawców w ich rękach, jako u osób cieszących się zaufaniem publicznym i gwarantujących upublicznienie rozporządzenia ostatniej woli.

Ponadto protokoły posiedzeń sądowych zawierają wzmianki o osobach, które stawiły się na otwarcie i ogłoszenie testamentu. Takie informacje odnajdujemy w 4 dokumentach ${ }^{56}$ : przy czynnościach otwarcia i ogłoszenia testamentu byli obecni małżonkowie zapisodawców ${ }^{57}$ i osoby składające testament ${ }^{58}$. Brak danych $\mathrm{w}$ pozostałych aktach najprawdopodobniej wynika z faktu, iż nikt z zainteresowanych nie stawił się na posiedzenie.

Na szczególną uwagę zasługuje protokół posiedzenia Sądu Pokoju Powiatu Zgierskiego z dnia 11 maja 1833 r. W treści tego dokumentu czytamy, iż na posiedzenie sądu oprócz wdowy po testatorze stawili się pełnomocnik nieobecnych sukcesorów zapisodawcy oraz notariusz Józef Stokowski, w którego kancelarii miał zostać złożony testament własnoręczny Rocha Kożuchowskiego. Fakt ten może świadczyć o jakimś konflikcie istniejącym między żoną testatora a pozostałymi sukcesorami i braku wzajemnego zaufania. Tym bardziej że Roch Kożuchowski zapisał swojej żonie na własność cały majątek ruchomy i dożywotnie użytkowanie wszystkich nieruchomości:

\footnotetext{
${ }^{50} \mathrm{JW}$., sygn. 2850.

${ }^{51} \mathrm{~Np}$.: Józef Stokowski, sygn. 3156.

${ }^{52} \mathrm{~Np} .:$ Roman Jaroński, sygn. 53.

${ }^{53}$ Jw., sygn. 284.

${ }^{54}$ Józef Stokowski, sygn. 6565.

${ }^{55} \mathrm{JW}$., sygn. 6379.

${ }^{56} \mathrm{JW} ., 2850,2106,3156,6565$.

${ }^{57} \mathrm{~Np}$.: Józef Stokowski, sygn. 2106.

${ }^{58} \mathrm{Jw}$., sygn. 6565.
} 
ruchomy przeznaczam całkowicie Moiey żonie bez ograniczenia - Nieruchomy żona moia Maryanna z Dąbrowskich używać ma prawo do śmierci bez obowiązku spłaty długów na tey nieruchomości ciążących.

W dalszej zaś części aktu zapisodawca podaje: „,wzywam sukcesorów, aby wolę moyą szanowali"59.

Sporządzający protokół zawsze podawali też wzmiankę o przedłożonym akcie zgonu zapisodawcy, np.:

My, Prezes, na skutek artykułu 1007 K.C. przychylając się do powyższego żądania po przekonaniu się z aktu zejścia, iż Tekla z Oszkowskich Borowska istotnie w dniu 21 grudnia 1839 r. zakończyła życie, przystapiliśmy do otwarcia ogłoszenia i opisania iey testamentu ${ }^{60}$.

Dokument z dnia 24 grudnia 1839/7 stycznia 1840 r., sporządzony przez księdza Fabiana Hirbergera proboszcza zgierskiego, stanowi wypis z ksiąg kościelnych parafii zgierskiej potwierdzający śmierć Tekli Borkowskiej:

Działo się w mieście Zgierzu dnia dwudziestego czwartego grudnia Tysiąc Osmset trzydziestego dziewiątego roku o godzinie dziesiątej przed południem. Stawili się Karol Brzeziński podpisarz Sądu Pokoju Powiatu Zgierskiego lat trzydzieści sześć liczący i Roman Jaroński Obrońca Sądu Pokoju Powiatu Zgierskiego lat trzydzieści siedem liczący obedway w Zgierzu zamieszkali i oświadczyli, iż dnia dwudziestego pierwszego bieżącego miesiąca i roku o godzinie dziesiątey w wieczor umarła w Zgierzu Tekla Borowska wdowa w Zgierzu z własnych funduszy utrzymująca się córka Józefa i Maryanny małżonków Oszkowskich lat czterdzieści ośm licząca. Po przekonaniu się naocznie o zejściu Tekli Borowskiej. Akt ten stawaiącym przeczytany przez nich podpisany został ${ }^{61}$.

Ponadto w protokołach odnajdujemy adnotacje, czy złożony testament był otwarty, czy zapieczętowany. Jedynie w 2 nie ma takich danych ${ }^{62}$, zaś z pozostałych dowiadujemy się, iż w 7 przypadkach testament złożono zapieczętowany ${ }^{63}$, a w 1 otwarty $^{64}$.

Prawie we wszystkich akatch znajduje się szczegółowy opis stanu przedstawionych testamentów. W pierwszej kolejności protokół zawierał wzmiankę, czy testament został sporządzony na papierze zwykłym, czy urzędowym,

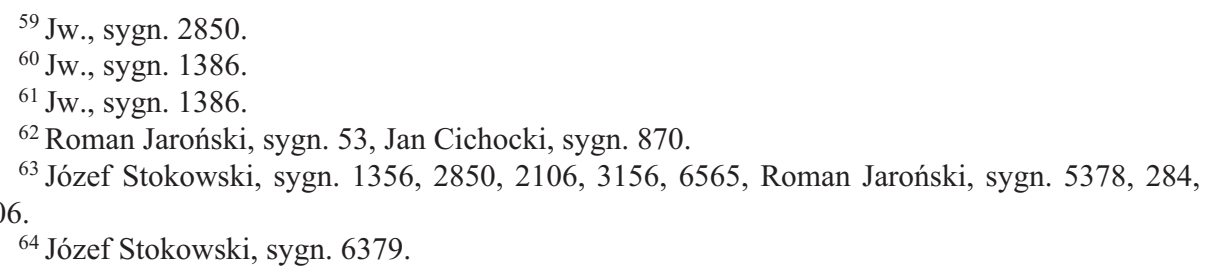

${ }^{64}$ Józef Stokowski, sygn. 6379. 
następnie sędzia podawał liczbę stron i wersów na każdej stronie oraz słowa, od których kolejne strony się zaczynały i na których kończyły. Ponadto wskazywano na ewentualne poprawki, dopiski i skreślenia.

Tak na przykład w protokole posiedzenia Trybunału Cywilnego I Instancji z dnia 20 sierpnia/1 września 1839 r. czytamy:

Złożone Nam, Prezesowi Trybunału, pismo testamentem księdza Wolkowicza być maiące, nieopieczętowane, na trzech Arkuszach papieru niestęplowego było spisane.

Na pierwszej stronie u góry był napis „Testament” - a po niżej słowa „W imię Oyca i Syna Ducha Świętego Amen”. Pierwszy wers samego rozporządzenia testamentowego poczynał się od słów: „na przypadek Zeyścia mego” - a ostatni, dwudziesty pierwszy, kończył się na słowie: „podpisałem” - pod tem była data w słowach „dnia dwudziestego dziewiątego lipca Tysiąc Osmset trzydziestego dziewiątego roku”, a następnie podpis „Ksiądz Kazimierz Wolkowicz proboszcz... Pod tym pismem ieszcze na pierwszej stronie zaczynało się zaparafowanie przez Sąd Pokoju Zgierski dopełnione od słów „Testament ninieyszy” - a na drugiey stronie było tego zaparafowania wierszy cztery. - Potem następowała data „Leźnica Wielka dnia dwudziestego osmego lipca/dziewiątego sierpnia Tysiąc Osmset trzydziestego dziewiątego roku".

$\mathrm{Na}$ trzeciej stronie u góry był napis: „Testament, w imię Oyca i Syna i Ducha Świętego Amen”. Pierwszy wiersz zaczynał się od wyrazów „Wiedząc dostatecznie”, a Osmy kończył się wyrazem „wartości”.

Na czwartej stronie było wierszy czterdzieści - w pierwszym był wyraz „transport”, a w ostatnim ,suma 408”. - W wierszu iedenastym pod wyrazem „ogniwami” - był dopisany wyraz ,żelaznymi”, w dwunastym dopisane wyrazy „par dwie”, w trzynastym wierszu po wyrazie „Wóz” był dopisany wyraz „szybowany”. Na piątej stronie było wierszy trzydzieści osm. W pierwszym były wyraz „Transport”, a w ostatnim liczba „trzysta osiemdziesiąt pięc”.

Na szóstej stronie było wierszy trzydzieści osm. W pierwszym były wyrazy „Transport 385” - a w ostatnim wyrazy „Suma dwieście siedemdziesiąt dziewięć".

Na siódmej stronie było wierszy dwadzieścia dwa pisanego wykazu w rubrykach - pierwszy zaś wiersz obejmował wyraz „Transport” - a ostatni słowa „Suma ogólna dwa tysiące Osmset osiemdziesiąt" - daley znowu następowało ciaggego pisma na tey stronie wierszy piętnaście - z których pierwszy poczynał się od słów „po spisaniu” - a ostatni kończył się na słowie „toaletka”

$\mathrm{Na}$ osmey stronie było pisanych wierszy trzydzieści siedem, z których pierwszy poczynał się od słów „toaletka” - a ostatni zawierał wyrazy „,efektów”. W wierszu dwudziestym piątym przed wyrazem ,,w katakumbie" dopisane były na marginesie wyrazy ,to iest”.

Na dziewiątey stronie było wierszy trzydzieści pięć, z których pierwszy poczynał się od „efektów siostrze” po czem następujący wyraz „zapisanych” był przekreślony, a ostatni obejmował wyrazy „nie mam procz długu”. 
Na dziesiątey stronie było wierszy dwadzieścia dwa, z których pierwszy poczynał się od słów „długu od Ciebie siostro”, a ostatni kończy się na słowie ,podpisałem”. Testament powyżej opisany oprócz wytkniętych dopisków i poprawek, żadnych więcey w sobie nie obejmował ${ }^{65}$.

Zastrzeżenia co do prawidłowego opisu stanu testamentu mogą dotyczyć protokołu z posiedzenia Sądu Pokoju powiatu zgierskiego z dnia 24 marca 1829 r. W dokumencie tym znajduje się jedynie opis stanu zewnętrznego dokumentu (koperty, w której zapieczętowano oświadczenie testatora), natomiast pominięto zupełnie opis pisma zawierającego samo rozporządzenie ostatniej woli:

zapieczętowany trzema pieczęciami w linii ciągłey, po za sobą będącemi - pieczęć jest prywatna, litera R znajduje się na niey. Wszystkie trzy pieczęcie czerwonem lakierem, zostaie bez naymnieyszego naruszenia, napis z drugiey strony iest co do słowa taki „ostatnia wola przez Ludwika Rakowieckiego własną ręką napisana u Wincentego Garczyńskiego składa za upoważnieniem”.

O ile sędzia w sposób szczegółowy wskazał stan zewnętrzny testamentu, o tyle opis pisma zawierającego ostatnią wolę testatora ograniczył się do zdawkowych informacji:

po otwarciu testamentu przekonaliśmy się daley, iż iest spisany na papierze prostym formatu arkuszowego własnoręcznie w dniu dwudziestym stycznia Tysiąc osmsetnego dwudziestego dziewiątego roku ${ }^{66}$.

3. Zapisodawcy. Niełatwo scharakteryzować osoby, które sporządziły testamenty własnoręczne. Dokumenty w dużej mierze nie zawierają istotnych danych, np. dotyczących wykonywanego zawodu, posiadanego potomstwa. Możemy jednak powiedzieć, iż rozporządzenia ostatniej woli $\mathrm{w}$ formie testamentu własnoręcznego częściej sporządzali mężczyźni $(6)^{67}$ aniżeli kobiety $(4)^{68}$. Analizowane dokumenty zawierają informacje dotyczące stanu cywilnego zapisodawców, choć dane te są niepełne (w 5 przypadkach brak jest jakichkolwiek danych $)^{69}$. Z dostępnych źródeł wynika, iż w 4 przypadkach testament sporządzili żonaci mężczyźni ${ }^{70}$, a w 1 kawaler $^{71}$. Niestety nie dowiadujemy się, czy testatorzy pozostawali w pierwszym, czy też kolejnym związku małżeń-

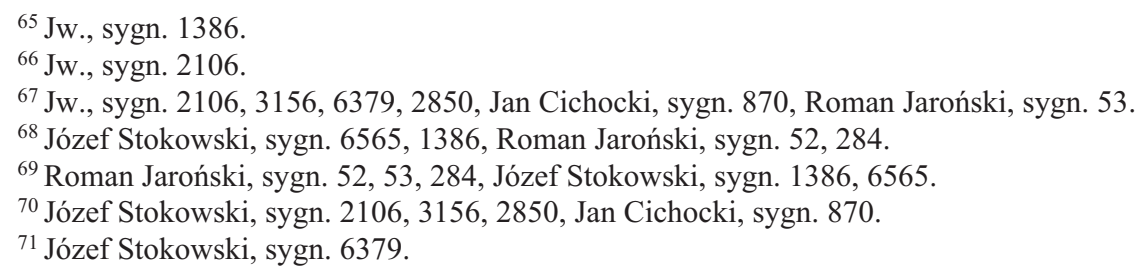

${ }^{71}$ Józef Stokowski, sygn. 6379. 
skim. Niewiele można też powiedzieć na temat zawodów wykonywanych przez zapisodawców, czy też ich statusu społecznego (jedynie w 4 przypadkach odnajdujemy jakiekolwiek informacje na ten temat) ${ }^{72}$; i tak, testamenty własnoręczne sporządziło 2 dziedziców dóbr ziemskich ${ }^{73}, 1$ czynszownik $^{74}$ i $1 \mathrm{ksiąa}^{75}$.

Zasadniczo dokumenty nie zawierają informacji, czy sporządzający testament posiadali zstępnych, czy też wstępnych. Jedynie 2 testamenty wskazują na fakt posiadania przez testatorów zstępnych ${ }^{76}$.

4. Zapisobiorcy. $Z$ zaledwie 6 testamentów wynika, iż w charakterze zapisobiorców zawsze powoływano osoby fizyczne, krewnych zapisodawców. Nie odnotowaliśmy przypadku, aby zapis testamentowy został dokonany na rzecz osoby spoza rodziny. Najwięcej zapisów zostało uczynionych na rzecz współmałżonków (4) ${ }^{77}$, przy czym zauważmy, iż brak jest dokumentów, z których wynikałby fakt posiadania małżonka i nieuczynienia na jego rzecz przysporzenia testamentowego. Współmałżonkowie nigdy nie dochodzili do spadku samodzielnie. Powoływano ich wspólnie z zstępnymi $(2)^{78}$, dziećmi rodzeństwa zapisodawcy $(1)^{79}$ lub też z innymi najbliższymi sukcesorami $(1)^{80}$.

W dokumencie z dnia 25 lutego 1829 r. Roch Kożuchowski zapisał swojej żonie dożywotnie użytkowanie wszystkich nieruchomości, natomiast prawo własności przeszło na rzecz bratanka Maurycego Kożuchowskiego:

maiatek nieruchomy żona moia Maryanna z Dąbrowskich używać ma prawo do śmierci... więc po śmierci mey żony na rzecz Maurycego Kożychowskiego syna brata mego Alexandra Kożuchowskiego ${ }^{81}$.

Na rzecz zstępnych dokonano 3 zapisów testamentowych, we wszystkich rozporządzeniach powołując dzieci do spadku wspólnie ze współmałżon$\mathrm{kami}^{82}$.

W testamencie z dnia 24 lutego 1833 r. August Lambrecht własność całego majątku w formie zapisu ogólnego przeznaczył córce, obciążając zapis prawem dożywotniego użytkowania na rzecz żony:

\footnotetext{
${ }^{72}$ Jw., sygn. 2106, 6379, Jan Cichocki, sygn. 870, Roman Jaroński, sygn. 53.

${ }^{73}$ Józef Stokowski, sygn. 2106, Jan Cichocki, sygn. 870.

${ }^{74}$ Roman Jaroński, sygn. 53.

75 Józef Stokowski, sygn. 6379.

${ }^{76}$ Roman Jaroński, sygn. 870, Józef Stokowski, sygn. 3156.

77 Józef Stokowski, sygn. 2850, 3156, 2106, Jan Cichocki, sygn. 870.

${ }^{78}$ Józefa Stokowskiego, sygn. 3156, Jan Cichocki, sygn. 870.

${ }^{79}$ Józef Stokowski, sygn. 2850.

${ }^{80} \mathrm{JW}$., sygn. 2106.

${ }^{81} \mathrm{JW}$., sygn. 2850.

${ }^{82}$ Jw., sygn. 3156, Jan Cichocki, sygn. 870.
} 
wszystko co tylko posiadam na przypadek nastąpić mogącey śmierci oddaję pod wyłączne bez ograniczenia moiey Żonie Tekli z Trzcińskich Lambrechtowey, a to w dożywotnie posiadanie... a po śmierci zaś moiey Żony maiątek ten przechodzi na córkę moią natenczas nieletnią Ludwikę ${ }^{83}$.

Ponadto źródła zawierają 2 zapisy na rzecz dzieci rodzeństwa. Raz siostrzeniec dziedziczył wspólnie z małżonkiem testatora ${ }^{84}$, a w drugim przypadku bratanica została powołana do spadku samodzielnie. W dokumencie z dnia 11 grudnia 1839 r. Tekla z Oskowskich Borowska powołała do całego spadku pod postacią zapisu ogólnego swoją bratanicę: „wszelkie rzeczy, które posiadam a nawet i te, które som w rekach osób konsygnacją obiętych przeznaczam i zapisuię Bratance mey Ludwice Koszuskiey" ${ }^{\prime 5}$. Niestety z aktu nie wynika, czy testatorka posiadała innych jeszcze sukcesorów koniecznych.

Odnajdujemy ponadto jeden zapis testamentowy na rzecz rodzeństwa ${ }^{86}$. W dokumencie z dnia 29 lipca/9 sierpnia 1839 r. ksiądz Kazimierz Wolkowicz, proboszcz parafii zgierskiej, zapisał cały majątek swojej siostrze, obierając ją jako jedyną spadkobierczynię: „na przypadek zejścia mego z tego świata całego mego majątku iaki mam i mieć mogę uniwersalną sukcesorką siostrę moią postanawiam". Testament nie daje jednak odpowiedzi na pytanie, czy zapisodawca miał sukcesorów koniecznych, o ile możemy zakładać brak zstępnych, to nie wiadomo, czy pozostawali przy życiu rodzice testatora.

Testator był zobowiązany do określenia zapisobiorcy w sposób niebudzący wątpliwości co do jego tożsamości, w przeciwnym razie rozporządzenie było nieważne ${ }^{87}$. Możemy wskazać 2 zapisy, które wzbudzają wątpliwość co do prawidłowości wskazania beneficjentów ${ }^{88}$. W aktach tych zapisobiorcy zostali określeni bardzo ogólnie poprzez sformułowania „sukcesorowi żony i najbliżsi moi sukcesorowi”, choć można założyć, iż zapisodawca miał na myśli sukcesorów dziedziczących w kolejności ustawowej.

5. Rodzaje rozporządzeń testamentowych. Zgodnie z treścią art. 895 $\mathrm{KN}$, „testament jest to akt, mocą którego testator rozporządza całością lub częścią majątku swojego, na czas, gdy już żyć nie będzie a który odwołać może".

Definicja testamentu zawarta w Kodeksie Napoleona może wskazywać, iż aktem tym można było dokonać jedynie rozporządzenia majątkowego. Jednakże ustawodawstwo Królestwa Polskiego i analiza materiału źródłowego wskazuje, iż XIX-wieczny testament był aktem, w którym testator nie tylko mógł

\footnotetext{
${ }^{83}$ Jw., sygn. 3156.

${ }^{84} \mathrm{JW}$., sygn. 2850.

${ }^{85} \mathrm{JW}$., sygn. 1386.

${ }^{86}$ Jw., sygn. 6379.

${ }^{87}$ F. Podlewski, O spadkach i testamentach ..., s. 113.

${ }^{88}$ Józef Stokowski, sygn. 2106, 2850.
} 
rozporządzić swoim majątkiem na wypadek śmierci, ale też dokonać za jego pomocą innych czynności. Pozamajątkowe postanowienia testamentowe możemy podzielić na 2 grupy. Pierwszą kategorię stanowią postanowienia wywołujące określone skutki prawne w sferze prawa osobowego, tj. ustanowienie opieki, dokonanie przysposobienia, uznanie dziecka naturalnego (tylko w testamencie publicznym), czy też zaprzeczenie pochodzenia dziecka (tylko w testamencie publicznym). Prócz wzmiankowanych czynności spotykamy także w XIX-wiecznych testamentach, w szczególności sporządzanych w formie publicznej, szereg oświadczeń woli składanych przez testatorów, które wprawdzie nie wywoływały bezpośrednio określonych skutków prawnych, ale stanowiły swego rodzaju zobowiązania natury moralnej nakładane przez testatora na spadkobierców czy rodzinę.

Kodeks Napoleona nie określał zamkniętego katalogu praw, które mogły podlegać dyspozycji na wypadek śmierci, tak więc mogły być to prawa rzeczowe, prawa autorskie, prawa patentowe oraz wszelkie inne prawa, o ile na mocy przepisów szczególnych mogły przejść na spadkobierców ${ }^{89}$. Jedynym warunkiem, co oczywiste, był wymóg, aby prawo majątkowe będące przedmiotem rozporządzenia testamentowego przysługiwało zapisodawcy ${ }^{90}$. W praktyce rozporządzano prawami rzeczowymi lub prawami obligacyjnymi $\mathrm{w}$ postaci wierzytelności.

Kodeks Napoleona nie wprowadzał żadnych ograniczeń w kwestii praw majątkowych, które mogły stanowić przedmiot zapisu testamentowego, a najczęściej przedmiotem zapisu testamentowego było przekazanie prawa własności. Jednakże występują także rozporządzenia testamentowe dające zapisobiorcy jedynie prawo użytkowania całego majątku (1) ${ }^{91}$, jego części (4) ${ }^{92}$ lub też poszczególnych rzeczy $(1)^{93}$.

Zgodnie z art. $895 \mathrm{KN}$ przedmiotem rozporządzenia testamentowego mógł być cały majątek lub jego część, zarówno ruchomy jak i nieruchomy ${ }^{94}$. Ustawodawca nie wyjaśnił, co oznacza całość, a co część majątku, czy w grę wchodzi przy całości tylko część rozrządzalna (część majątku podlegająca swobodnej dyspozycji testatora), czy także to, co należało się z ustawy. Praktyka notarialna wskazuje, iż całość majątku rozumiano jako całkowity posiadany dobytek, a nie tylko jego część podlegającą swobodnej dyspozycji.

${ }^{89}$ F. Kramsztyk, Wykład popularny prawa cywilnego i handlowego obowiqzujacego w Królestwie Polskim, Warszawa 1917, s. 31; H. Konic, Otwarcie i objęcie spadku, wykład porównawczy na tle prawodawstw obowiazujacych $w$ Polsce $w$ zestawieniu z kodeksem szwajcarskim, Warszawa 1923, s. 1-4.

${ }^{90}$ H. Konic, Otwarcie i objęcie spadku..., s. 1-4.

${ }^{91}$ Józef Stokowski, sygn. 3156.

92 Jw., 2850 (3 zapisy), Jan Cichocki, sygn. 870.

${ }^{93}$ Józef Stokowski, sygn. 2106.

${ }^{94}$ Art. $895 \mathrm{KN}$ - „Testament jest to akt, przez który testator rozporządza całością lub częścią majątku swojego, na czas, w którym już żyć nie będzie, i który odwołać może”. 
Materiały źródłowe dają podstawę do twierdzenia, iż testatorzy zazwyczaj dysponowali w testamencie własnoręcznym całym posiadanym majątkiem. Jedynie testament z 20 stycznia 1829 r. nie daje nam odpowiedzi na pytanie, czy testator rozporządził w nim całym posiadanym majątkiem. $Z$ dokumentu wynika, iż Ludwik Rakowiecki przekazał własność wsi Sułkowice najbliższym sukcesorom, obciążając jednocześnie zapis prawem dożywotniego użytkowania na rzecz swojej żony. Ponadto w akcie odnajdujemy zapis należnych testatorowi wierzytelności. Niestety brak jest w treści rozporządzenia jakiejkolwiek informacji, czy dyspozycje te wyczerpały całą schedę spadkową ${ }^{95}$.

Każde rozporządzenie majątkowe na wypadek śmierci mogło zostać dokonane w jednej z 3 form przewidzianych przez Kodeks Napoleona, tj. zapisu ogólnego ${ }^{96}$, zapisu pod tytułem ogólnym ${ }^{97}$ i zapisu szczególnego ${ }^{98}$. Ustawodawca nie przewidywał $\mathrm{w}$ tym zakresie żadnych ograniczeń z uwagi na przedmiot rozporządzenia. Również praktyka nie wykształciła w tym względzie żadnego zwyczaju, z badanych akt notarialnych wynika, iż wszelkie nieruchomości, jak i ruchomości były przekazywane zapisobiorcom w formie wszystkich 3 przewidzianych przez prawo zapisów.

$\mathrm{W}$ analizowanych testamentach własnoręcznych odnajdujemy 4 zapisy ogólne ${ }^{99}, 5$ zapisów pod tytułem ogólnym ${ }^{100}$ i 3 zapisy szczególne ${ }^{101}$.

Przypadek zapisu ogólnego możemy wskazać w testamencie z 28 lipca/9 sierpnia 1839 r. Zapisodawca, ksiądz Kazimierz Wolkowicz, w formie zapisu ogólnego przekazał cały majątek siostrze: „na przypadek zejścia mego z tego świata całego mego majątku iaki mam i mieć mogę uniwersalną sukcesorką siostrę moią postanawiam" 102 .

Zaś w dokumencie $\mathrm{z}$ dnia 5 lutego $1831 \mathrm{r}$. odnajdujemy zapisy pod tytułem ogólnym. Roch Kożuchowski w swoim rozporządzeniu majątkowym na wypa-

${ }^{95}$ Józef Stokowski, sygn. 2106.

${ }^{96}$ Art. $1003 \mathrm{KN}$ - „Zapis ogólny jest rozporządzenie testamentowe, przez które testator daje jednej lub kilku osobom ogół majątku, jaki z dniem swojej śmierci pozostawi”.

${ }^{97}$ Art. $1010 \mathrm{KN}$ - „Zapis pod tytułem ogólnym jest ten, przez który testator zapisuje część ilą majątku, jakim prawo dozwala mu rozrządzać, jako to, połowę, trzecią część, albo wszystkie swoje nieruchomości, albo wszystkie swoje ruchomości, albo oznaczona, część wszystkich swoich nieruchomości, albo wszystkich swoich ruchomości. Każdy inny zapis jest tylko rozporządzeniem pod tytułem szczególnym".

${ }^{98}$ Zapisem szczególnym było każde rozporządzenie, które nie mieściło się w definicji zapisu ogólnego i zapisu pod tytułem ogólnym. Pogląd ten, choć powszechnie przyjmowany i akceptowany, nie wynikał wprost z przepisu prawa. Art. $1010 \mathrm{KN}$ odnoszący się jednie do istoty zapisu pod tytułem ogólnym, stanowił, iż „każdy inny zapis jest tylko rozporządzeniem pod tytułem szczególnym”, co może sugerować, iż w pojęciu zapisu szczególnego powinno także się mieścić rozporządzenie w formie zapisu ogólnego.

99 Józef Stokowski, sygn. 6379, 1386, 3156 (2 zapisy).

${ }^{100} \mathrm{Jw}$., sygn. 2850 (4 zapisy), Jan Cichocki, sygn. 870.

${ }^{101}$ Jan Cichocki, sygn. 870, Józef Stokowski, sygn. 2106.

102 Józef Stokowski, sygn. 6379. 
dek śmierci rozdysponował całym swoim majątkiem w formie 4 zapisów pod tytułem ogólnym:

Majątek ruchomy przeznaczam własnością moiey żonie bez ograniczenia, nieruchomy żona moia Maryanna z Dąbrowskich używać ma prawo do śmierci. Po śmierci żony pozostałość na dwie części być ma, to iest połowa dla sukcesorów prawnych moiey żony, a druga dla Maurycego Kożuchowskiego ${ }^{103}$.

Tak więc w cytowanym fragmencie odnajdujemy zapis pod tytułem ogólnym własności wszystkich ruchomości, dożywotniego użytkowania wszystkich nieruchomości oraz dwa rozporządzenia pod tytułem ogólnym części nieruchomości.

Natomiast przykład zapisu szczególnego występuje w akcie z 30 kwietnia 1858 r., w którym Józef Smoleński uczynił na rzecz swoich dzieci zapis pieniężny: „uczyniłem udział dla dzieci rubli trzy tysiące dziewięćset razem”"104.

Testamenty własnoręczne zawierają także dyspozycje w zakresie nałożenia na poszczególnych zapisobiorców obowiązku spłaty długów spadkowych $^{105}$. W testamencie z dnia 25 lutego 1831 r. Roch Korzuchowski zapisał cały majątek nieruchomy w dożywotnie użytkowanie swojej żonie Maryannie z Dąbrowskich, zobowiązując ją jednocześnie do spłaty długów obciążających nieruchomości:

Majątek nieruchomy żona moia Maryanna z Dąbrowskich ma używać do śmierci, lecz obowiązana spłacić długi na tey nieruchomości ciążące mianowicie Panu Gutkowskiemu złotych sześć tysięcy, Panu Antoniemu Malczewskiemu złotych siedemset trzynaście, Leonardowi z Jagodnicy złotych dziewięćset ${ }^{106}$.

Testament mógł zawierać też pewne rozporządzenia o charakterze niemajątkowym. W testamentach własnoręcznych możemy wyróżnić tylko jeden taki przypadek. W dokumencie z dnia 24 lutego 1836 r. August Lambrecht ustanowił opiekuna dla swej nieletniej córki: „opiekunem nad nieletnią Córką moją Ludwiką Lambrechtową upraszam Pana Andrzeja Jezerwicza"107.

6. Wykonawca testamentu. Instytucja wykonawcy testamentu jest instrumentem mającym zapewnić prawidłowe i rzetelne wypełnienie ostatniej woli testatora oraz zapobiec sporom między dziedzicami. Wykonawca testamentu jest pełnomocnikiem spadkodawcy powołanym do wykonania rozporządzeń testa-

\footnotetext{
${ }^{103}$ Jw., sygn. 2850.

104 Jan Cichocki, sygn. 870.

${ }^{105}$ Józef Stokowski, sygn. 3156, 2850,

${ }^{106} \mathrm{JW}$., sygn. 2850.

${ }^{107} \mathrm{JW}$.
} 
mentowych. To pośmiertne pełnomocnictwo w zasadniczy sposób różni się od zwykłego pełnomocnictwa. Może ono być udzielone jedynie przez testament. Ponadto zwykłe pełnomocnictwo wygasa z chwilą śmierci mocodawcy, w tym wypadku przeciwnie, dopiero się rozpoczyna. Oprócz tego pełnomocnictwo zwykłe w każdej chwili może zostać odwołane, natomiast pełnomocnictwa do wykonania testamentu, co wynika z samej jego istoty, odwołać nie można, skoro mocodawca udziela pełnomocnictwa, które nabiera mocy dopiero w chwili, gdy udzielający je traci zdolność prawną ${ }^{108}$. Zgodnie z treścią art. $1025 \mathrm{KN}$, „testator może mianować jednego lub kilku wykonawców testamentu".

W badanych testamentach własnoręcznych występują 2 przypadki powołania egzekutora spadku. Tak w dokumencie z dnia 11 grudnia 1839 r. Tekla Brzozowska, która zapisała cały majątek pod postacią zapisu ogólnego bratanicy, powołała wykonawcę testamentu w słowach następujących: „Exekutorem zaś testamentu tego i ostatniey dyspozycji Money obieram i ustanawiam Karola Brzezińskiego"109. Testatorka nie wskazała szczegółowo zakresu obowiązków wykonawcy testamentu ani też kim był dla niej Karol Brzeziński. W testamencie z dnia 24 lutego 1833 r. August Lambrecht, który rozdysponował posiadany majątek pomiędzy żonę i córkę, mianował wykonawcę testamentowego w osobie Andrzeja Jezerwicza. Podobnie jak w powyższym przykładzie, testator nie wskazał precyzyjnie zakresu czynności egzekutora ani nie określił relacji wiążącej go z powołaną osobą. Jednak w tym przypadku możemy przypuszczać, iż Andrzej Jezerwicz musiał być w bliskiej relacji z testatorem, gdyż oprócz funkcji wykonawcy jego ostatniej woli August Lambrecht powierzył mu stanowisko opiekuna swojej nieletniej córki: „Egzekutorem testamentu i opiekunem nad nieletnieą córką moią Ludwiką Lambrechtową upraszam Pana Andrzeja Jezerwicza, który obowiązki te dobrowolnie na siebie przyjmuje" ${ }^{110}$.

7. Odwolanie testamentu. Zgodnie z brzmieniem art. $895 \mathrm{KN}$ testament jest aktem, przez który testator rozporządza swoim majątkiem na wypadek śmierci i który w każdej chwili może zostać przez niego odwołany ${ }^{111}$, choćby prawa tego uprzednio zrzekł się $e^{12}$. Może on zmienić swoją decyzję i w odmienny sposób niż poprzednio rozporządzić swoim majątkiem na wypadek śmierci lub zrezygnować z indywidualnej decyzji ${ }^{113}$. Kodeks Napoleona przewidywał różne sposoby odwołania testamentu. Dokonanie tej czynności mogło wynikać z woli zapisodawcy lub orzeczenia sądu. Spadkodawca mógł wyrazić

\footnotetext{
${ }^{108}$ A. Okolski, Zasady prawa cywilnego..., s. 413-414.

109 Józef Stokowski, sygn. 1386.

${ }^{110}$ JW., sygn. 3156.

${ }^{111}$ Art. $895 \mathrm{KN}$ - „Testament jest to akt, przez który testator rozporządza całością lub częścią majątku swojego, na czas, w którym już żyć nie będzie, i który odwołać może".

112 Wyktad praw obowiazujacych w Królestwie Polskim, t. I: Prawo cywilne, b. m. i d. w., s. 260.

${ }^{113}$ E. Skowrońska-Bocian, op. cit..., s. 191-192.
} 
swoją wolę w sposób wyraźny lub dorozumiany. Wyraźne odwołanie rozporządzenia ostatniej woli następowało przez sporządzenie testamentu wprost odwołującego poprzedni akt lub też w formie oświadczenia złożonego przed notariuszem ${ }^{114}$. Milczące odwołanie miało natomiast miejsce, gdy testator, nie odwołując poprzedniego rozporządzenia, sporządził nowy testament, którego treść nie dała się pogodzić z wcześniejszym bądź sprzedał lub zniszczył zapisaną rzecz ${ }^{115}$.

Tak też testator mógł odwołać np. drugi testament za pomocą trzeciego lub też przywrócić ważność testamentu pierwszego albo też odwołać jednym aktem kilka wcześniejszych rozporządzeń ostatniej woli.

W badanych źródłach występuje tylko 1 przypadek odwołania w testamencie własnoręcznym wcześniejszych rozporządzeń ostatniej woli. W akcie z dnia 20 stycznia 1829 r. zawarte zostało oświadczenie Ludwika Rakowieckiego w słowach następujących: „wszystkie moie rychlejsze czyli dawniejsze testamenta odwołuje takową ostatnią i rozmyślną wolę moią chce mieć co do słowa skuteczną"116. Dokument nie zawiera jednakże informacji o liczbie wcześniejszych rozporządzeń ostatniej woli czy też ich formie.

8. Podsumowanie. Testament własnoręczny obwarowany minimum formalności, wymagający zasadniczo od zapisodawcy jednie umiejętności pisania nie cieszył się zbyt dużą popularnością. Jaka mogła być tego przyczyna? Wydaje się, iż ten stan rzeczy mógł wiązać się, z jednej strony, ze znacznym analfabetyzmem społeczeństwa, a drugiej - z obawą zapisodawców, iż ich ostatnia wola nie zostanie wykonana na skutek np. zniszczenia czy ukrycia rozporządzenia przez pominiętych krewnych. W tym miejscu należy poczynić uwagę, iż wysnute wnioski mogą być opatrzone znacznym błędem, gdyż tak naprawdę nie wiemy, jaka była rzeczywista liczba sporządzanych testamentów własnoręcznych, wiele z nich mogło nie zostać przedstawionych Prezesowi Trybunału I instancji do otwarcia i ogłoszenia, a co za tym idzie o ich istnieniu nigdy się nie dowiemy.

Analiza źródeł daje pewne podstawy do przypuszczenia, iż zapisodawcy nie zawsze mieli pełną świadomość w zakresie wymogów prawnych odnoszących się do testamentu własnoręcznego. Świadczą o tym wskazane dokumenty spisane przez osoby obce czy też sporządzone w obecności świadków.

Zgromadzone testamenty własnoręczne zawierają niewiele informacji na temat tak zapisodawców, jak i zapisobiorców. Ogólnie można stwierdzić, iż były to osoby posiadające zazwyczaj majątek tak ruchomy, jak i nieruchomy,

\footnotetext{
${ }^{114}$ Prawo cywilne... na podstawie wykładów uniwersyteckich prof. H. Konica..., s. 466.

${ }^{115}$ E. Skowrońska-Bocian, op. cit., s. 192.

116 Józef Stokowski, sygn. 2106.
} 
które w charakterze zapisobiorców powoływały jedynie najbliższą rodzinę, dokonując zapisów we wszystkich 3 przewidzianych przez Kodeks Napoleona formach. $\mathrm{Z}$ analizy dokumentów wypływa wniosek, iż zapisodawca podejmował decyzję o sporządzeniu testamentu własnoręcznego w sytuacji, gdy nie było konfliktu między zapisobiorcami co zakresu i przedmiotu sched spadkowych.

Warto zwrócić uwagę, iż w testamenty własnoręczne właściwie nie zawierają rozporządzeń natury niemajątkowej, i tylko w jednym dokumencie miało miejsce ustanowienie opieki; podobnie inne postanowienia, jak ustanowienie wykonawcy testamentowego czy odwołanie poprzednich rozporządzeń testamentowych, zdarzają się rzadko. 